\title{
The Influence of Virtual Physics Laboratory On Senior High School Form One Physics Students' Performance And Cognitive Achievement At Bishop Herman College, Kpando, Volta Region- Ghana
}

\author{
Asare Alexander Hero Yawo
}

\begin{abstract}
The main objective of this study was to find out the influence of virtual physics laboratory on students' performance and cognitive achievements in motion. The total population for the study was 63 second year science students; 42 in the control group and 21 in the experimental group at Bishop Herman College, Kpando. Quasiexperimental design was adopted in this study. Questionnaire, test and were the research instruments used. The data were analyzed by using SPSS 16.0 statistical analysis program and statistics such as mean, Standard Deviation were calculated and a paired sample t-test technique was used. The mean test score of the experimental group (22.2) was higher than their control group (13.6) counterparts in the post-test. The $t$ - test analysis of the mean score on the post-test shows a significant difference between the 2 groups $(t=5.465 ; p<0.05)$. There is a significant difference between the participation of the students who were exposed to the VPLAB approach and their counterparts who were exposed to the traditional approach. The finding of the present study clearly revealed that students learned concept of motion effect through virtual physics lab in a better way as compared to teaching in abstract.
\end{abstract}

\section{BACKGROUND TO THE STUDY}

Students perceive information in different ways. That is why teachers use variety of teaching strategies to improve students' learning. Educational systems around the world are under pressure to use information and communication technologies (ICTs) to enhance teaching and learning. There are many ways to present new and challenging information in teaching and learning. Computer programmes allow the incorporation of pictures, sounds and animation into teaching and learning which extends the teachers capacity to present lessons that encourage students' interaction with the subject matter. It is evident that the students at the second cycle schools are becoming more advanced in the use of technology.

Physics is one of the major aspects of science which students in Ghana dislike. Research conducted by Wanbugu and Changeiywo (2008) classified physics as difficult subject, not popular, avoided by students and with poor performance in schools. This researcher observed that this assertion also pertains to the science students of Bishop Herman College, Kpando where this study was done. The researcher, observed that most science students at Bishop Herman College passed very well in other science subjects after carefully going through their exercise books and also their performance in their final examination but perform poorly in Physics. It was in this regard that this study examined the option of using virtual physics laboratory to enhance teaching and learning of physic in Bishop Herman College, Kpando.

\section{STATEMENT OF THE PROBLEM}

The use of multimedia in teaching in the second cycle is not encouraging. As a result, physics students' participation and cognitive achievement in physics was very low. The researcher realized that, the students' interest in motion was very low. He found out that, most students could not solve simple problem under the topic correctly. Motion has always been a problem to Senior High School students offering physics. For this reason, the researcher used Computer program (VPLAB) to teach in order to determine the effect of the program on the students' performance with respect to motion. The use of the program was supplemented with the use of pedagogical strategies such as group work; hands-on learning and technology enhanced learning techniques to achieve the needed results.

\section{Objectives}

The objectives of the study were as follows:

1. To identify factors that affected the students' participation and performance in motion.

2. To determine the outcome of the use of VPLAB on students' cognitive achievement.

\section{Research Questions}

The research questions below serve as a guide in the investigations:

1. What factors influence students' participation and performance in motion?

2. What are students' cognitive achievement in motion when they are taught using the VPLAB

Null hypothesis

The following null hypotheses were formulated for the study:

1. $\mathrm{H}_{\mathrm{O}}$ : There is no significant difference between the cognitive achievements of students and the use of VPLAB in lessons on motion.

Educational Significance of the Study 
The outcome of this study will go a long way to enhance the teaching and learning of motion at Senior High Schools in Ghana.

The use of VPLAB in teaching mechanics enable students to visualize scientific concept "dynamically and authentically" (Jackson, Krajcik \& Soloway, 2000) and stir up their interest.

The use of VPLAB would also bring to light possible misconception which when addressed would enhance students' understanding. To curriculum developers and designers, the success in the use of VPLAB in the teaching and learning of motion would give them a new perspective in recommending its use across the educational system.

\section{REVIEW OF RELATED LITERATURE}

\section{ICT integration in teaching and learning of physics}

Technology has been a party of schooling for many decades but until recently the technologies being used were rather simple and changed slowly. When the field of physics developed the area of electronics, cheaper gadgets have been manufactured and their production, demand and uses have dramatically increased. To underscore this, in 1983 there were just about 50,000 computers in American schools (Stantrock,2004). With the introduction of cheap modems and competing internet service providers a teacher in the rural areas can easily access the internet and specifically for this study there are various websites that have physics videos and physics animations that can be downloaded to suit any topic within the Ghanaian curriculum. Besides, video cameras and DVD players were previously having a prohibitive price but now, any school that wishes to invest in this hardware can do so as their prices has really gone down. Unlike other science subject's physics has many demonstrations that can be recorded and considering that the basic scientific principles do not change any recorded videos can be used without getting outdated. The internet is the core of computer mediated communication. In many cases it has more current up-to-date information than the physics text books. This would therefore be of great use to the teachers in keeping abreast with immerging issues in the subject so as to be at par with the rest of the world. Howell and Dunnivant, (2002) argued that only when schools have technologically trained teachers and current workable technologies will the technology revolution have an opportunity to truly transform classrooms.

\section{Factors that affect students' performance in Motion lessons}

According to Keeves and Mrganistern (1992), attitude of the learner affects performance. This was also supported by Anderson (2006) who explained that attitude and achievement are related and that a positive attitude towards science lesson results in a good achievement.
Teachers' content and pedagogical knowledge is a key factor to students' academic success in today's classrooms (Darling-Hammond, 2000). Therefore, what teachers know, determines the authenticity of their contribution to teaching and learning of motion. The pedagogical content knowledge of a teacher is also crucial in teaching and learning of concepts in Physics.

Other factors that affect students' performance in Mechanics lesson are: past experiences of the learners, material availability, presentation of concepts and topics in an abstract. This leads to 'inert knowledge' knowledge not related to the environment of learners.

lack of motivation, time available for teaching and learning, learning strategies students employ and selfefficacy are also identified as factors affecting student performance in physic

\section{The importance of Students' Perceptions on Motion}

How learners form concepts was a very important issue in science education today. Researches on students' misconceptions have become a central issue in science education for the past two decades because they are presumed to be instruction-resistant obstacles to the acquisition of scientific concepts (Lawson, 1988). Much research therefore has been focused on what accounts for misconception in science and steps to correct the situation. It is well established in higher education that students arrive at universities with already conceived misconceptions which can exist alongside new conceptions and are marked by being personal in nature, counter intuitive, highly resistant to change and/or contradictory (Wandersee, Mintzes \& Novak, 1994). This assertion is also true about students who come to Senior High Schools. The sources of misconception may be diversified.

More often than not science teachers' instructions usually focus on covering all the topics in the course syllabus or manual without a consistent emphasis on integrating across concepts.

Physics is an exciting subject that underpins much of modern technology and is vital to the economic wellbeing of the world and to our human appreciation of our true place in the physical universe.

\section{Description of the Virtual Physics Lab. (VPLAB)}

Computer Software are well designed concept-driven packages of instructional materials that support and facilitate teaching and learning in a classroom or laboratories. They are designed to be more adaptable for general use. Teachers could use them as supplement and enhancement of their own teaching methods.

The Virtual Physics Laboratory (VPLAB) is an on-line simulation-based learning environment allowing students to conduct "virtual experiments" which feature many characteristics and constraints normally associated with real experiments, such as: uncertainty of measuring apparatus, small random fluctuations of parameters, and 
limitations in the range or control that the experimenter has over parameters and variables.

For each experiment, the VPLAB environment also offers explanations and demonstrations in a multimedia format (video clips of real experiments, interactive explanations concerning mathematical and (or) physical considerations, etc. that closely match up against the simulated experimental set-up

\section{Research Design}

The research design used in this study was quasiexperimental. A quasi-experiment is an empirical interventional study used to estimate the causal impact of an intervention on target population without random assignment. One of the groups acts as an experimental group and the other as the control group.

\section{Population}

A research population is a large well-defined collection of individuals or objects having similar characteristics (Castillo, 2009). The accessible population was all the sixty-three (63) second year science students of Bishop Herman College in the Volta Region of Ghana.

\section{Sample and Sampling Procedures}

Purposive sampling technique was used to select the sample for the study. Makhado (2002) supports the use of purposive sampling technique for quasi experimental design by stressing on the fact that it is important to select information rich cases as this will help the researcher to address the purpose of the research. McMillan and Schumacher (2001) further recommended purposive sampling because the samples that are chosen are likely to be knowledgeable and well informed about the phenomenon the researcher is investigating. It was against this background that the researcher used purposive sampling to select the sample for the study. The sample selected for this study was made up of two second year science classes of 42 and 21 students respectively.

\section{Instrumentation}

Questionnaire and test were the instruments used for collecting data about the students before and after the interventions.

\section{Data Analysis}

Data collected were analyzed using the Statistical Package for Social Science (SPSS) version 16.0 for windows 2007. The pre-test and posttest scores of students were analyzed statistically using paired sample t-test with equal variances on both the pre-test and the post-test scores to discover if any significant difference exists between the pre-test and the post-test of the experimental and the control groups.

Presentation of results, analysis and discussion Research question 1: What factors affects students' participation and performance in the teaching of motion?

Responses to the questionnaire items were presented in tables and expressed in terms of percentage for further analysis.

The results in Table 1 provide information on 12 factors which were identified to influence the participation and performance of students in the teaching of motion.

\section{Table 1: Factors Affecting Students' Participation and Performance in the Teaching of Motion:}

\begin{tabular}{|c|c|c|c|}
\hline $\mathbf{S} / \mathbf{N}$ & Statement & $\begin{array}{l}\text { Freq. Yes } \\
(\%)\end{array}$ & $\begin{array}{l}\text { Freq. No } \\
(\%)\end{array}$ \\
\hline 1. & Do you like Physics? & $20(26)$ & $43(74)$ \\
\hline 2. & Do you like the topic motion? & $42(63)$ & $21(37)$ \\
\hline 3. & $\begin{array}{l}\text { Was your first year physics teacher harsh on you during the teaching of } \\
\text { motion? }\end{array}$ & $48(72)$ & $15(28)$ \\
\hline 4. & $\begin{array}{l}\text { Did the use of the lecture method only by your Physics teacher affect } \\
\text { your participation in motion lessons? }\end{array}$ & $49(73)$ & $14(27)$ \\
\hline 5. & $\begin{array}{l}\text { Do you think lack of motivation from your current Physics teacher can } \\
\text { cause you to participate less in physic (motion) lessons? }\end{array}$ & $49(73)$ & $16(30)$ \\
\hline 6. & $\begin{array}{l}\text { Could learning environment increases students' participation and } \\
\text { enjoyment in motion lesson? }\end{array}$ & $60(90)$ & $3(10)$ \\
\hline 7. & $\begin{array}{l}\text { Could students with weak mathematics background participate less in } \\
\text { motion lessons? }\end{array}$ & $55(82)$ & $8(18)$ \\
\hline 8. & $\begin{array}{l}\text { Could students who have fewer interactions with colleagues on motion } \\
\text { topics learnt previously participate less in current lessons? }\end{array}$ & $37(55)$ & $26(45)$ \\
\hline 9. & Can the use of the internet by students to find out more about motion & $19(28)$ & $44(72)$ \\
\hline
\end{tabular}


cause them to participate less in motion lessons?

10. Could learners' attitude towards the learning of motion make them 51 (76) participate less in its lessons?

11. Could excessive co-curricular activities cause students to participate less 54 (81) in motion lessons?

12. Could lack of the relevant textbooks cause students to participate less in $49(73)$ motion?

From Table 1, it was observed that 20 and 43 (26\% and $74 \%$ ) of the students who were given the questionnaires showed dislike of physics lessons and motion lessons respectively. Seventy two percent (72\%) of the respondents agreed that physics teachers who were harsh on them affected their participation in their lessons.

A high proportion (73\%) of the students agreed that the use of lecture method only made learning of motion boring and affected their understanding and participation. Students who received motivations from their teachers and other colleagues participate better in physics lessons than those who do not. This was confirmed by $73 \%$ of the respondents.

A high proportion of ninety percent $(90 \%)$ of the students agreed that learning environment increases students' interest and participation in motion lesson. Eighty two percent $(82 \%)$ of the students were of the opinion that weak mathematical background affects their participation in motion lesson. Fifty- five (55\%) of respondents confirmed that interaction with friends on previous motion lessons made them understand the concept being taught them.
Twenty eight percent (28\%) of the respondents confirm that the use of the internet helps them to acquire in-depth knowledge in motion. Seventy six percent $(76 \%)$ of the respondents agreed that their attitude towards the learning of motion made them participate less in its lessons. Eighty one percent $(81 \%)$ of the respondents stated that excessive co-curricular activities caused them to participate less in lessons on motion. Seventy three percent $(73 \%)$ of the respondents also strongly believed that lack of relevant textbooks cause them to participate less in motion lessons.

Research question 2: What are students' cognitive achievements in motion when they are taught using the VPLAB method?

To answer this research question, a pre-test was conducted on the experimental group. Table 2 shows the data on the outcomes of the test. In addition, a null hypothesis as formulated and tested to help answer the question.

Table 2: Frequency Distribution of Pre-test Scores of Students in the Experimental

\begin{tabular}{|c|c|c|}
\hline Scores & Frequency & Percentage $(\%)$ \\
\hline
\end{tabular}

\begin{tabular}{|c|c|c|}
\hline $0-5$ & 6 & 28.6 \\
\hline $6-10$ & 9 & 42.8 \\
\hline $11-15$ & 5 & 23.8 \\
\hline $16-20$ & 1 & 4.8 \\
\hline $21-25$ & 0 & 0 \\
\hline $26-30$ & 0 & 0 \\
\hline
\end{tabular}

TOTAL 21

100

From Table 2, it can be seen that 6 students representing $28.6 \%$ had marks between 0 and 5 . While $42.8 \%$ of students had marks between 6 and 10 . Some $23.8 \%$ of students scored between 11 and 15, whereas $4.8 \%$ of students hard marks between 16 and 20. It can also be observed from the Table 3 that none of the students scored from 21 to 25 and 26 to 30 respectively. The distribution of post-test scores of students in the same group (experimental) is displayed in Table 3. It could be observed from the table that there was a remarkable 

intervention.

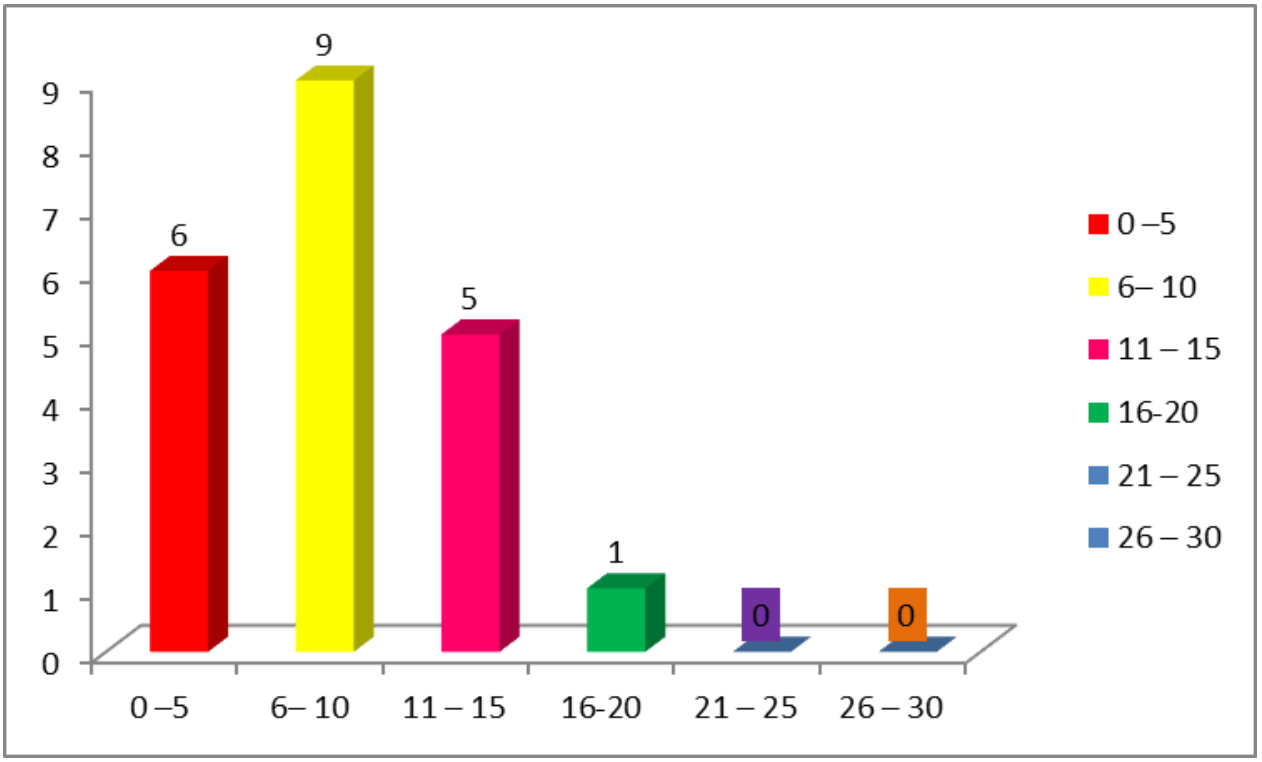

Fig: 1 Distribution of Pre-test Scores of Students in the Experimental Group

Table 3: Frequency Distribution of Post-test Scores of Students in the Experimental Group

\begin{tabular}{ccc}
\hline Scores & Frequency & Percentage $(\%)$ \\
\hline $0-5$ & 0 & 0 \\
$6-10$ & 0 & 0 \\
$11-15$ & 1 & 4.8 \\
$16-20$ & 4 & 19 \\
$21-25$ & 9 & 42.9 \\
$26-30$ & 7 & 33.3 \\
\hline Total & 21 & 100
\end{tabular}

In Table 3, none of the students scored between 0 to 5 and 6 to 10 respectively. Some $4.8 \%$ of them scored between

Fig 2
11 and 15 , whilst as much as 42.9 scored between 21 and 26. 


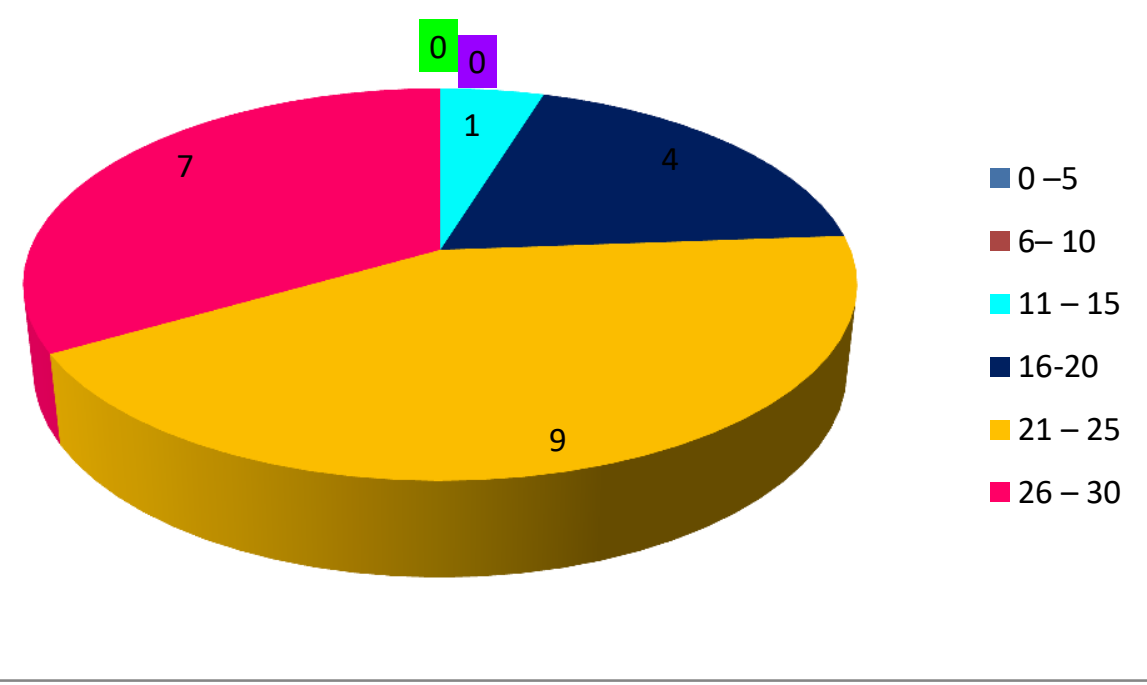

Distribution of Post-test Scores of Students in the Experimental Group

\section{Testing of Null Hypothesis One}

$\mathrm{H}_{\mathrm{o}}$ : There is no significant difference between the cognitive achievements of students and the use of VPLAB in lessons on motion.

A paired sample t-test result conducted to determine the difference between the cognitive achievement of students in the pretest and post-test is also shown in Table 5.

Table 4: T-test Results of Pre-test and Post-test Scores of the Experimental Group

\begin{tabular}{lccccc}
\hline Compared Group & N & Mean Score & S.D & d.f & p-Value \\
\hline Pre-test & 21 & 8.3 & 4.33 & 19 & $0.002^{*}$ \\
Post-test & 21 & 22.4 & 3.6 & & \\
\hline
\end{tabular}

$*$ = Significant $; \mathrm{p}<0.05$

The generated p-value of 0.002 was less than the probability level of 0.05 , thus indicating that there was a significant difference in the performance of students in the experimental group in the pre-test and post-test.

\section{Discussion}

The discussion is undertaken with respect to each of the two research questions.

Question 1: What factors affect students' participation and performance in motion?
Examination of Table 1 revealed that the majority of the students showed dislike of physics and motion lessons respectively.

Learning physics is often considered by teachers and students to be a difficult pursuit. Over the last two decades a great deal of educational research has been directed towards the exploration of students' ideas and difficulties on physical concepts and processes (Driver, Guesne \& Tiberghien,1985; Duit, Goldberg \& Nidderer, 1991).The findings of the study revealed that physics teachers who were harsh on students affected their participation in their lessons. This seems to be in line with 
the idea of Tatar (2005) who says that teachers' emotional disposition affects students' participation in class.

The results of the study indicated that the use of lecture method only makes learning of motion boring and affects understanding and participation of students. Wanbugu and Changeiywo (2008) suggested that for better achievement of students in physics there should be changes in teacher's method of teaching because using appropriate teaching method is central to a successful learning of physics. Motivation has been shown to positively influence study strategy, academic performance adjustment and wellbeing in students in the domain of education. (Vansteenkiste et al. 2005) This was confirmed by the outcome of the study.

The findings of the study came out that learning environment, increases students participation and increases students enjoyment. This seems to be in consonance with Caldwell (2007) who stated that creating an active learning environment, increases participation and increasing students' enjoyment

The study proved that weak mathematical background affects students' participation in motion lesson and Umbach (2006) claimed that a strong link between subject specific self-efficacy with choice of a particular discipline such as high mathematics self-efficacy.

The study also confirmed that interaction with friends and other people on motion lessons learnt make them understand the concept being taught them. This was in consistent to Gilles (2003) who believed that group discussions and interactions assist other peers to learn through explaining of topics to each other. Peer learning is a method of instruction that has proven to be effective especially in the physics education community (Caldwell, 2007). According to Caldwell (2007), the interaction between students is the value of peer instruction, in the sense that students share similar characteristics, including age, language and common experience.

The study attested to the fact that the use of the internet helps physics students to acquire in-depth knowledge in motion. Kerdprasop and Kerdprasop (2008) confirmed that Web-based learning environments have the advantages of reusability, interoperability and accessibility, provided by the Internet, which play a crucial role in the development of modern learning environments. The web has become a popular application for online learning (Nam \& Smith-Jackson, 2007) largely because the web is currently at a point where it is possible to stream video, have audio-conferencing, podcasts, video casts and more (Anderson, 2008). It was established from the study that students' attitude towards the learning of motion makes them participate less in its lessons. This also supported Anderson (2006) explained that attitude and achievement are related and that a positive attitude towards science lesson results in a high achievement.

The outcome of the study confirmed that excessive cocurricular activities before and after motion lessons cause students to participate less. This finding also gives credence to Wambach and Brothen (1997) assertion that engaging students too much in activities that are irrelevant to a particular topic to be studied or studied affects their performance.

It was strongly confirmed and believed from the study that lack of relevant physics textbooks cause learners to participate less in motion lessons. This finding strongly confirmed the findings of Ornstein (2006) which states that learning in abstract without relevant textbooks and other teaching and learning materials affects students' participation and performance in classroom learning.

Research Question 2: What are students' cognitive achievements in motion when they are taught using the VPLAB method?

It is evident in Table 4 that the cognitive achievement of the experimental group improved in the post-test. Seels (2011) suggested that technology influence learning.

The performance of the experimental group improved. The performance of the experimental group after the intervention indicated that the intervention strategy was very effective hence such improved performance. This was in line with the argument made by Miller (2001) that the use of technology in the classroom increases knowledge and expands the understanding of learners. The findings gave credence to Tavukeu (2008) who stated that computer-based learning approach in science training affect students' positively and improve students' scientific skills.

This chapter summarizes the findings in the entire research concerning the use of VPLAB to enhance students' performance. This chapter also includes a conclusion derived from findings, leading to the ideas that gave the recommendation for further research that this study did not tackle because of time and resources.

The students were more interested in using VPLAB.

\section{Recommendations}

1. The learners ${ }^{e e}$ motivation can greatly be enhanced by making physics lesson more resource based in creating 
variety in the lessons when multimedia are used to reinforce what is learnt.

2. Teachers should be encouraged to use virtual environment and demonstrations that are now readily available from the internet as part of their teaching resource. As technology improves, cheaper and more convenient software will be available.

3. Schools should purchase good computers along with projectors or large screen monitor and have them networked. This allows students participation using the available technology.

4. The sequence in which a teacher uses VPLAB also proved to be challenging in the research. Whether the VPLAB should be use before the lessons or after the lesson depends upon the contents of the topic.

\section{REFERENCES}

[1] Anderson, I. K. (2006). Umpolished PhD. Thesis; University of Western Cape. In I. D. (Ed), Research on science teacher education as seen by Ghanaian Junior Secondary School Students.

[2] Anderson, T. (2008). Towards a theory of online learning. . In In T. Anderson (Ed.), Theory and Practice of Online (pp. 45-74.). Edmonton AB: AU Press.

[3] Caldwell, J. E. (2007). Clickers in the large classroom:Current research and best -practice tips CBE. Life Science Education, 6,9-20.

[4] Castillo, J. M. (2009). A problem solving/ Response to Intervention model as System. Communique, 35(8), 34,36,38-40.

[5] um for Schools and Programme for Teacher Development .

[6] Darling-Hammond, L. (2000).

[7] Teacher Quality and Student Achievement: A review of StatePolicy Evidence.

[8] Retrieved from Education Policy and Archives Website:http://epaa.asu.edu/epaa/v8n1

[9] site. Retrieved August 9, 2004, from www.technowlogia.org.

[10] Driver, R., Guesne, E., \& Tiberghlien, A. (1985). Children's ideas in science. Milton Keynes: Open University Press.

[11] Gilles, R. M. (2003). The Effect of Cooperative Learning on Junior High School Students During Small Group Learning. Learning and Instruction , 14,197-213.

[12] Howell, J., \& Dunnivant, S. (2002). Models of teaching. New Haven,CT: New Haven Public schools.

\section{Conclusion}

VPLAB mainly improve learners ${ }^{e e}$ theoretical concepts formation process skills and participation in motion lessons. This research has shown that there is great potential in VPLAB as a teaching aid that can turn around the poor performance in physics if the right content is available to the learners. With the rapid development in technology in the country, data transfer will be much cheaper but so far, specific content to the curriculum is not sufficient more so in the field of sciences.

Generally, the conclusion of the study was that computerassisted instruction had a positive effect on student learning on both the control group and the experimental group.

[13] Keeves, J. P., \& Margenstern, C. (1992). Attitude Towards Science Measurement and Effect. Changes in Science Education and Achievement, 9,122-140.

[14] Kerdprasop, N., \& Kerdprasop, K. (2008). Knowledge Mining in Webbased Learning Environments. International Journal of Social Sciences , 3(2), 80-84

[15] Lawson, A. E. (1988). The acquisition of biological Knowlege during childhood:Cognitive conflict or tabula rasa. Journal of Research in Science Teaching , 25,185-199.

[16] Makhado, N. D. (2002). Challenges educators experiences in the provision of environmental education at schools in curriculum 2005. Johannesburg: Rand Afrikaans University.

[17] McMillan, J. H., \& Schumacher, S. (2001). Research in education; a conceptual introduction (5th ed). New York London.

[18] Miller, S. (2001). Technology: What's it good for. Learning and Learning With Technology, 28(6),42-45.

[19] Nam, C. S., \& Smith-Jackson, T. L. (2007). Web-based learning environment: A theory-based design process. Journal of Information Technology Education , 6, 23- 44.

[20] Ornstein, A. (2006). The Frequency of Hands on Experimental and Student Attitude toward Science. A Statistical Significant Relation Journal of Science Education \& Technology , 15(3),285-295.

[21] Seel, B. (2011). From Dale to Delivery Systems: The Problem od Media Selection Theory. In G. Anglin, Instructional Technolog, Past Present and Future (3rd Ed") (pp. pp. 55-68). Santa Barbara: CA: Libraries Unlimited. 
[22] Stantrock, W. J. (2004). Education psychology. New York: Mc Graw-

hill.

[23] Tatar, S. (2005). Why Keep Silent? The Classroom Participation Experiences of Non-Native English Speaking Students in Language and Intercultural Communication , 5,284-293.

[24] Tavukcu, F. (2008). Fen Egitiminde bilgisayar Destekli Ogrenme Ortaninin Ogrencilerin Akademik Basari, Bilimsel Surec Becerileri ve Bilgisayar Kullanmaya Yonelik Tutuma Etkisi. Yayinlanmis Yuksek Lisans Tezi. TKU Sosyal Bilimler Enstitusu.

[25] Umbach, P. D. (2006). The contrubution of faculty of colour to undergraduate education. Research in High Education , 47(3),317342.

[26] Vansteenkiste, M., Zhou, M., Lens, W., \& Soenens, B. (2005). Experiences of autonomy and control among Chinese learners:Vitalizing or immobilizing? Journal of Educational Psychology, 97(3),468-483.

[27] Wambach, C., \& Brothen, T. (1997). Teacher Self-Disclosure and Student Classroom Participation Revisited. In teaching of psychology, $24,262-263$

[28] Wanbugu, P. W., \& Changeiywo, J. M. (2008). Effect of mastery learning approach on Secondary school students" ${ }^{\text {ee }}$ physics achievement. Eurasia Journal of mathematics, Science \& technology education, , 4(3), 293-302.

[29] Wandersee, J. H., Mintzes, J. J., \& Novak, J. D. (1994). Alternative conception in science. New York: Macmillan Publishing Company.

Asare Alexander Hero Yawo, Department of Science, Bagabaga College of Education, Box35 ER, Tamale-Ghana 